\title{
- Conclusion
}

- By focusing on late-nineteenth-century authors such as Zola, the Goncourt brothers, Maupassant, Mirbeau, and Uzanne, I have sought to uncover ways in which male writers created a kind of fetishistic fiction pegged on simulations of a woman's consciousness. Exploring epiphenomena distilled from a fin-de-siècle culture of femininity-bibelot-collecting, sartorial narcissism, religious selfstigmatization, maternal melancholia, and the sadomasochistic phantasms surrounding maid service-I examined the ways in which forms of female fetishism unrecognized as such by psychoanalysis intersected with male fetishizations of femininity. In this way, a lost chapter of psychoanalytical history (female perversion) was, in a sense, filled in by a chapter of literary history (replete with late naturalist chronicles by men of female passions, manias, and attachments).

There were, of course, important women novelists in this period who wrote comparably fetishistic fictions combining the sexologicalsociological memoir with realist-naturalist stylistics. Zulma Carraud, Gyp, Séverine, Rachilde, and Colette all engaged to some extent in this literary project. Their contribution merits a separate study concentrating, for example, on the role of the female authorial voice in turn-of-the-century representations of sexual obsession and perversion. My concern here has been primarily with the question of why male authors at this time devoted themselves so consistently to writing about feminine clothing, feminine eccentricities, feminine interior visions. The answer is no doubt traceable in 
part to that European fin-de-siècle crisis in masculinity which, according to Elaine Showalter, spawned self-servingly masculinist versions of sexual difference. ${ }^{1}$ Fetishism was particularly amenable to being used to this end, for perhaps more than any other "perversion," it emphasized the phallus and provided through its language of substitution, artifice, and displacement a unique psychological and aesthetic means of disguising Victorian-era castration anxiety.

By emphasizing the degree to which male authors of this period depended on fetishistic fictions of femininity I have tried to feminize the fetish itself, de-monumentalizing the fiction of castration anxiety predominant even today, locating a kind of female phallus in the sartorial superego, and dislodging (if ever so slightly) gendered canon alignments.

This said, I should hasten to add that it would be delusionary to think that revisionist readings of misogynist texts on the decorated, fetishized female body (as in the bejeweled nudity of Salammbô and Salomé) suffice to redeem them for a "new" canon. An irredentist gynophobia comes to the fore even when one tries to salvage historic "feminine perspectives" from literary characterizations of women by men. Mirbeau, for example, forged a connection between the love of looking at cruelty (fetishistic Schaulust) and female erotomania in Le Jardin des supplices that can only be described as profoundly misogynistic. In his Oriental torture garden, spectacles of pain are presented as "what a woman wants," while the male narrator, looking on, disculpates himself of his own scopic desire by fetishizing it in the gaze of a femme fatale. Turn-of-the-century writers, one could argue, seem to have been terrified of discovering what was behind a woman's gaze. Their punishment of the female observer who dares to look (Pandora) emerges as a recurrent misogynist tactic. Ultimately, one might say, it was necessary to perpetrate a myth of feminine scopophilia to safeguard the right to fetishize women: if woman was "in fact" castratory (both on the symbolic level and the real), then the male subject was fully justified in making parts of her body the object of displacement.

Rarely in the male-authored fin-de-siècle novel is the reader allowed to see what a woman sees without layers of misogynist mediation in itself complicitous with psychoanalytical orthodoxies

1. Elaine Showalter, Sexual Anarchy: Gender and Culture at the Fin de Siècle (New York: Viking Penguin, 1990), pp. 8-18. 
and commonplaces. The woman's gaze is invariably "hysterical," barred by the law (lex talionis), "veiled" in tears, or maniacally, preoedipally affixed to a partial object at the expense of a totalizing picture. Though one could perhaps argue that this impaired vision of partial objects "adds up" to seeing what one wants to see, more of ten than not it appears in the works of male authors to be a symptom or scar marking the site of organs that have been removed or made to disappear.

Though throughout this study I have tried to thwart these scotomizations of the female body by restoring a face to the prostitute, mystic, or maid, it has been difficult to constitute a "mistress" gaze. Nor is looking to woman writers of the period necessarily helpful. When Mirbeau launched Marie-Claire (1910)-the working-class novel by an autodidactic seamstress named Marguerite Audoux - with a preface lauding her rendering of "the spectacle of the everyday," he gave his relentless misogyny a temporary rest. $^{2}$ But Marie-Claire is an example of humble, submissive écriture féminine - of prose that is timid, regional, circumspect, and myopic in its field of vision. More subversive was a work written by his own wife, Alice Regnault, rumored to have been a prostitute skilled in specialty vices before becoming Mirbeau's spouse. Mademoiselle Pomme, published in 1886 some thirteen years prior to The Torture Garden and now fallen into obscurity, is the intimately told biography of a well-to-do courtesan's daughter stigmatized in society by her mother's profession. Full of informative glimpses of the daily life of kept women in the belle époque, the novel contains one particular scene that, read in tandem with equivalent scenes in Mirbeau's Torture Garden, shows the "difference" of a woman's scopic fix:

C'était une femme, une de ses malheureuses qui, tous les soirs, moyennant trois francs, servent de décor vivant, d'enseigne en vrai, à ces établissements spéciaux, qui venait d'avoir une attaque de nerfs.

On se rassura.

—Ohé! ohé ...criiii!... fit une voix qui imitait le cri de douleur parti de la scène.

Quelques applaudissements ironiques éclatèrent. Des miaulements,

2. Octave Mirbeau, preface to Marie-Claire (Paris: Charpentier, 1910), p. viii. Audoux's novel is a largely autobiographical, sentimental, pastoral, deeply Christian account of an orphan's life, first in a "pension," and then as a shepherdess gradually acclimated to brute poverty. Though its sickly sweetness makes it almost unreadable today, Mirbeau praised the work for its "taste, depth, ... and force of interior action" (p. vii). 
des aboiements, des gloussements, des cocoricos se répondirent d'un bout à l'autre du jardin.

-Ohé! ohé...criiii! répéta la même voix.

C'était très gai. On rit, on chanta, on accompagna, en frappant avec les cannes les tables, les verres et les carafes, la malheureuse dont les cris devenaient à chaque instant plus déchirants, plus douleureux, et donnaient la sensation d'une chose horrible, d'un corps tordu par la souffrance et qui se roulait et se débattait, comme en une eff royable agonie.

-Ohé! ohé ... criiii.

Et le rideau se releva.

En effet, une place était vide; un mouchoir, un éventail brisé, une fleur froissée, jonchaient encore le tapis rouge. Un monsieur s'avança, et l'orchestre attaqua un air chahutant de quadrille. Le monsieur s'égosilla, la grosse caisse, les cymbales, les pistons firent rage, essayant de couvrir le cri sous leurs hurlements déchaînés, mais ce cri de la femme dominant tous les bruits, s'éleva plus strident, courut, plus rapide, sur tout ce tâpage.

Et rien n'était poignant dans ce bastringue, en cette luminère fausse, sous ces arbres déverdis, parmi tous ces gens hébétés, comme ce cri de douleur, ce râle de suppliciée qui rythmait cet air enragé de cancan.

-Rentrons, dit Lina toute pâle.

It was a woman who had just had a nervous attack, one of those unfortunates who, for an average of three francs a night, served as live décor, a kind of human sign, in these special establishments.

Everyone was reassured.

"Ahh! ahh! criiii!" screamed a voice, imitating the cry of pain that came out from the stage.

Several bursts of ironic applause erupted. Meowing, barking, clucking, crowing, filled the garden from end to end.

"Ahh! ahh! criiii!" the same voice repeated.

It was very festive. People laughed, sang, and pounded tables, glasses, and pitchers with their canes accompanying the unfortunate woman, whose cries became at each moment more searing and painful, giving the sensation of a horrible thing, of a body, contracted by suffering, struggling, rolling around in frightful agony.

"Ahh! ahh! criiii!"

And the curtain came up again.

In effect, there was an empty spot; nothing but a handkerchief, a broken fan, a pressed flower, remained strewn over the red carpet. A gentleman came forward and the orchestra kicked up a raucous dance tune. The gentleman began to shout, the kettle drum, cymbals, and percussion raged on, trying to bury the woman's cry beneath their uncontrollable bellows. But the cry of this woman dominated the racket, 
rising ever more stridently, running ever more rapidly over all the din.

And there was nothing poignant in this dive, in this false light, under the leafless trees, among all these dazed people, save for this cry of pain, this death-rattle of the tortured one, in step with the enraged rhythm of the cancan.

"Let's go home," said Lina, very pale. ${ }^{3}$

Where Mirbeau's Clara rejoices at seeing male and female bodies in pain, Regnault's Lina balks at the sight of theatricalized cruelty, illustrating how male conventions for representing feminine scopophilia break down when the author is a woman. Here the contrast between male and female constructions of the woman's gaze can be resumed as follows: Mirbeau, allowing Clara to see too much, capitalizes on her sadism to make his humanist case, whereas Regnault generates a psychic space of identification out of what is not seen by her female viewer. Lina, in listening, must look away, and one might conclude that Regnault achieves a more subtle critique of specular cruelty by denying visual access to the scene of transgression. Representing the poor actress as a lack registered only faintly by a broken fan, a handkerchief, and a flower; posing a public "eargasm" over and against misogynist Schaulust (as in Mirbeau's novel), she refuses to gratify the reader's voyeurism. Displacing the affective charge from the eye to the ear, she performs an operation that is fundamentally fetishistic, but fetishistic in the service of human sympathy rather than in the service of an illusion of sexual mastery. By compelling the reader to focus on the "blue angel" atmospherics of collective barbarism rather than on the erotically splayed body of a torture victim, she forces us to listen to the "real" sound of human suffering instead of leaving us "dazzled" by the blinding images of pornographic violence. Sympathetic to her prostitute-heroine, just as her prostitute-heroine is sympathetic to the unfortunate creature screaming offstage, Regnault implicitly refutes vampiric models of fin-de-siècle femininity.

Though one would not want to overdetermine essentialist expectations regarding vision, voice, and gender difference, this passage from Mademoiselle Pomme provides nonetheless an emblematic example of how closely associated authors of opposing genders distributed the burden of visual punishment in an era of oculocentric naturalist poetics. In contrast to her husband, Alice Regnault not only refuses the popular fin-de-siècle topos of Medusa's gaze, she

3. Alice Regnault, Mademoiselle Pomme (Paris: Paul Ollendorff, 1886), pp. 50-52. 
also forgoes that quintessential naturalist icon-the clinical death scene-in which the body of the fallen woman, disintegrating into a mess of putrefaction, is transformed into a kind of carrion feast for the eye.

Though Mirbeau and his contemporaries exploited naturalism's phobic visualizations of the female body to the extreme, they also, as I have argued throughout this book, distinguished themselves as experts on the detailism of feminine culture. Perhaps they could be said to have fetishized femininity for homeopathic purposes: fixating on how women masked their manque à être (lack in being), focusing on a woman's distancing of manliness through an impostor's show of womanliness, misogynist authors distracted themselves all the more effectively from any reminder of phallic deficiency. It is in this context that the supreme attention paid to "femme-ness" becomes more readily decipherable. The secret details of an elegant feminine toilette, microsociologies of flirtation and seduction, careful notations of the totemic perfume bottles and Meissen figurines that composed and particularized a woman's surroundings at the century's end, these recurrent descriptive obsessions can be read as so many managements of lack, involving the exchange of one kind of phallic prosthetics (the classic fetish) for another (the masquerade of femininity), more susceptible to mastery. As Daniel Sibony has recently argued, "perversion is not the transgression of limits, but rather the establishment within limits of fetishes that one can master."

Another way of looking at this exchange of missing referents might be in terms of a double fetishism whereby male writers are seen to be pretending to be women pretending to be men. By recuperating the errant masculinity of the "woman with a masculinity complex," they garner, second hand, a means of successfully masquerading as men! The paradox, of course, is that this very move to impersonate maleness via the femininity masquerade transformed antifeminist male authors into the guardians and avatars of cultural feminization.

4. Daniel Sibony, "Des liens pervers et toxicos," in Libération, July 1 7, 1990, p. 5. 